\title{
RELATIONSHIP ANALYSIS BETWEEN DISCLOSURE ON THE INTERNET, RISK AND RETURN IN LATIN AMERICAN COMPANIES
}

\section{TALIEH SHAIKHZADEH VAHDAT FERREIRA}

$\mathrm{PhD}$ student in Management from the Department of Management, Federal University of Paraíba (UFPB).

Master's Degree in Management from the Department of Management, Federal University of Paraíba (UFPB).

UFPB, Campus I, Cidade Universitária - João Pessoa - PB - Brasil - CEP 58051-900

E-mail: taliehv@gmail.com

\section{ORLEANS SILVA MARTINS}

$\mathrm{PhD}$ in Accounting from the Department of Accounting and Actuary,

University of Brasília (UnB).

Professor at the Department of Finance and Accounting,

Federal University of Paraíba (UFPB).

UFPB, Campus I, Cidade Universitária - João Pessoa - PB - Brasil - CEP 58051-900

E-mail: orleansmartins@yahoo.com.br 


\section{ABSTRACT}

Purpose: This study sought to examine the extent to which the internet it is utilized as a tool for the disclosure of corporate information, facilitating the transparency of companies in relation to their stakeholders. Originality/gap/relevance/implications: This study differs from previous as it fills a gap in the literature to relate a disclosure measure on the internet with the risk and return of companies in Latin America, since this literature is only possible to identify studies that analyze these variables independently or with respect to other factors.

Key methodological aspects: The sample included 758 companies listed on four major exchanges in Latin America (Argentina, Chile, Brazil and Mexico), and its disclosure level was quantified and its relationship with risk and return were verified by Tobit regressions.

Summary of key results: The results show that it is possible to observe that the issue of ADRs, the size and liquidity affect the relationship between disclosure, risk and return. Also, the disclosure has advanced in the region over the years, especially in Brazil. However, no significant differences were identified between the countries, to the point of impact relations with the risk and return of companies.

Key considerations/conclusions: The main contributions are the expansion of evidence on these variables, relating them to each other in emerging markets.

\section{KEYWORDS}

Disclosure. Index. Information. Capital market. Latin America.

\section{INTRODUCTION}

Corporate disclosure is defined by Bushman, Piotroski and Smith (2004) as the set of relevant and reliable information disclosed periodically by cor- 
porations, including their financial situation, investment opportunities, corporate governance and market risk. According to Chong and Lopez-de-Silanes (2007), the demands of capital market for higher disclosure levels gained momentum especially after the financial scandals of the early 2000s, involving large corporations, like Enron and WorldCom, which motivated different discussions about its content and its regulation.

Consequently, Aksu and Kosedag (2006) indicate that these events triggered unprecedented government intervention in the US capital market, the largest in the world, resulting in the enactment of Sarbanes-Oxley Act. This move was followed by several countries which started to restructure their own laws and regulations to ensure the implementation of the best corporate governance practices and got the required disclosure level to monitor the activities of managers and the performance of corporations, thus offering greater protection to investors (Aksu \& Kosedag, 2006). In this context, Latin American countries tend to have low legal protection to shareholders and weak enforcement of laws (low enforceability), which consists of an opportunity for companies to differentiate themselves by adopting different practices of corporate governance and disclosure (Garay \& Gonzalez, 2008).

With regard to corporate disclosure, Bushman et al. (2004) point out that it depends on the channel through which the information is disclosed, since this channel can contribute to greater availability of information, increasing the economic effect of information. For Orens, Aerts and Cormier (2010), with the advancement of communication technologies, the use of the internet as an information dissemination tool has gained a new dimension and importance in the relationship of firms with investors. This is also highlighted by Garay et al. (2013), who note that, until the beginning of XXI century, the dissemination of corporate information was conducted mainly through physical reports, which often made the speediness of its presentation unsatisfactory and its accessibility not equal for all investors, favoring the existence of information asymmetry. With the advent of the disclosure through the internet, such problems have been minimized.

In this context, it is possible to observe that it is relevant to the analysis of other information dissemination media, in addition to traditional means (Ettredge, Richardson, \& Scholz, 2002; Geerings, Bollen, \& Hassink, 2003; Bollen, Hassink, \& Bozic, 2006; Gandia, 2008; Orens et al., 2010). However, most of this research has focused on the analysis of the information disclosed and its effects, regardless of the mode being used for disclosure, which is ratified by Garay et al. (2013). In parallel, Gandia (2008) states that economic crises have increased the interest of regulators in regulating not only the content, but also the way the information is disclosed 
Added to that, the relevance of this issue is justified because of its relationship with risk and return of companies. Garay et al. (2013) identify empirically this relationship, affirming that the better the disclosure, the lower the information asymmetry and hence the risk of the company. Thus, this study aims to analyze the relationship between the disclosure of information published through the Internet, the risk of information, and the return of business in Latin America.

The focus on Latin American countries becomes relevant as emerging countries have an additional motivation to improve their disclosure process, as they seek to attract an increasing number of investors who consider transparency as one of the most significant indicators in their decision making, which has the power to positively impact company's value (Hermalin \& Weisbach, 2012). This study differs from previous ones as it fills a gap in the literature by relating a disclosure measure on the internet with the risk and return of companies in Latin America, since in this literature is only possible to identify studies that analyze such variables independently or in relation to other factors. Their relations and the effects of external factors that may affect such relationships are analyzed.

From its main results, it is possible to verify, through the comparison with the evidence of Garay et al. (2013), that there is advance signals in the level of disclosure of these companies. The relation of this disclosure with risk was only negative and significant among the companies with American Depository Receipts (ADRs) traded in US, while the relationship of the disclosure with return was only positive and significant for companies with greater market liquidity. Thus, it stands out as one of the main contributions of this study is the signaling of its evidences, not only for academics, but also for investors and regulatory bodies, of which effectively are the effects disclosure expansion on the internet over the risk and return of Latin American companies.

\section{THEORETICAL BASIS}

\subsection{Market efficiency and agency conflicts}

The Efficient Market Hypothesis (EMH) assumes that in an efficient market asset's prices provide accurate signals for the allocation of capital (Fama, 1970). However, Fama (1991) relaxes this assumption by stating that those prices are influenced by various types of information depending on the market context, the relevance of information and timing that they take to be incorporated by the market. 
In this market, Jensen and Meckling (1976) emphasize that the separation of ownership and company's management created space to the agency conflict in which owners often are dependent on the information disclosed by the company management to monitor the return on investment. Further, based on La Porta et al. (1998), it is possible to observe that in Latin American countries, where the property is commonly concentrated in the hands of a few shareholders (controllers), this issue gives rise to an information asymmetry between controlling and minority shareholders.

In this sense, seeking to protect investors and improve the functioning of their capital markets, each country has developed a legal framework to minimize the effects of agency conflicts. However, La Porta et al. (1998) point out that this protection may vary significantly between countries around the world, because it is strongly related to the origin of the right of each country. Countries of Anglo-Saxon origin, such as the US and Britain, have their legal structure based on common law, which provides greater protection to investors and ensures a strong law enforcement, creating an environment conducive to spraying company stock. On the other hand, Latin American countries have a legal framework based on civil law, which tends to have low shareholder protection and weak enforcement of laws. In this scenario, information asymmetry opportunities expand.

\subsection{Disclosure relationship with risk and return}

According to Patel, Balic and Bwakira (2002), in countries with low legal protection the disclosure plays an important role as it can partially compensate low protection to investors generating a positive impact on the market value and in the company return. In this sense, Bushman et al. (2004) point out that corporate disclosure can be defined as the set of relevant and reliable information disclosed by corporations periodically covering their financial situation, investment opportunities, corporate governance and market risk. However, the disclosure cannot be confused with information, since its meaning is broader, referring to the widespread dissemination (Murcia \& Santos, 2009).

In terms of return measurement, in the literature it can be found a number of indicators. For Love (2011) and Perez (1995), the performance analysis of companies can be divided into operational performance, market value and share return. However, it is necessary to divide them into financial returns and economic returns. Based on the latter, return indicators are pointed out as Return on Assets (ROA), Return on Equity (ROE), Total Return to Shareholders (TRS) and Return to Creditors (RC). According to 
Love (2011), these indicators sets provide information about the revenue generation capacity by the company under different criteria. In Latin Ameri$\mathrm{ca}$, studies that relate disclosure to companies returns are scarce, but there is evidence that their relationship with company's value is positive (Lefort, 2005; Chong \& Lopez-de-Silanes, 2007; Garay \& Gonzalez, 2008).

With the development of markets in Latin America, the discussions about informational efficiency also gain feature, especially as regards the use of inside information. As the misuse of inside information may cause investors to avoid investing in these markets due to fear of being harmed (Martins \& Paulo, 2014), it is relevant to consider whether the use of the internet as a means of corporate information dissemination has contributed to expand company's disclosure and, consequently, to reduce information asymmetry.

Martins and Paulo (2014) point out that among the main risk factors for a company is the information risk, derived from the information asymmetry between market participants. For them, different studies have sought to measure the existence of information asymmetry and, as information risk cannot be measured directly, it has been utilized different proxies, such as market-to-book, volatility, intangibility and beta. Yet, as the existence of more information on the market tends to reduce this asymmetry, it is possible to expect a negative relation of disclosure with company's information risk (Ettredge et al., 2002; Martins \& Paulo, 2014).

However, when financial performance measures are not favorable to the companies, Ettredge et al. (2002) note that they tend to select the information disclosed by reducing their voluntary disclosure. This meets what Bollen et al. (2006) claim once managers tend to be concerned with maintaining competitiveness and consciously not using all the disclosure of options offered by the Internet, seeking to protect their competitive advantage. They also point out that companies with higher financial returns (ROA and ROE) tend to build their websites in order to give greater emphasis to its good performance, promoting a greater volume of information than required by regulators. Therefore, it is possible to expect a positive relationship of disclosure with the return (Bollen et al., 2006; Garay et al., 2013). On the other hand, both TRS and RC are related to capital risk (own or third party), so it is reasonable to expect a negative relationship of disclosure with these measures (Verrecchia, 2001; Botosan \& Plumlee, 2002).

With respect to the means of disclosure, a tool that has played a key role is the internet, especially in the frequency and speediness with which information is shared with investors. In finance literature, it is possible to identify its importance as a channel of communication between companies and 
investors (Ettredge et al., 2002; Geerings et al., 2003; Gandia, 2008). However, the vast majority of studies focused in Latin America do not consider the use of the Internet as a means of disclosure. Being one of the few with this approach, Garay et al. (2013) emphasize that higher levels of disclosure in this region tend to be positively associated with obtaining better operating performance, since most transparent companies tend to be better evaluated by the market.

\section{METHODOLOGICAL STEPS}

In order to measure the disclosure, a common method used is the construction of indexes, once by quantifying the disclosure enables the establishment of models that seek to identify its relation to risk and return factors (Feyitimi, 2014). In studies that consider the internet as a means of disclosing information, it is necessary to restrict data collection period to a short period of time to mitigate potential unavailability of information or significant changes derived from the internet itself (Deller, Stubenrath, \& Weber, 1999).

Additionally, it is important to consider that data collection related to layouts or company's websites updates, identifying information (disclosure) available in these websites cannot be made retroactively, which means, it can only be done in a certain moment in time (at the present). Thus, the collection of information on the sites was restricted to 2015 (related to the financial data of 2014), not being possible to collect retroactively information as we do not have access to previous layouts of companies websites.

Thus, the collection of data was based on three sources: (i) Thompson Reuters for all financial data; (ii) companies' websites, in the Investor Relations section; and (iii) JP Morgan website for ADRs data issuing. It is noteworthy that country's data negotiated company's stock were considered the, whether a subsidiary or headquarters. Cross listings were disregarded. Thus, the population covered all companies listed on the BCBA (Argentina), on the BM\&FBOVESPA (Brazil), the BCS (Chile) and the BMV (Mexico). Only companies that presented all the necessary data for analysis were considered, being excluded investment funds. At the end, remained in 858 non-financial companies, among which it was not possible to identify the website of 100 of them. Thus, the sample analyzed concerned of 758 companies, distributed as follows: 81 companies in Argentina (11\% of the sample); 358 in Brazil (47\%); 187 in Chile (25\%); and 132 in Mexico (17\%). 


\subsection{Definition of variables}

To measure the disclosure of companies, we chose to use the model developed and tested by Garay et al. (2013), through the Internet-based Corporate Disclosure Index (ICDI) as a variation of Geerings et al. (2003) index, applied to emerging markets with the addition of corporate governance elements. In this sense, it is not the focus of this study to propose amendments or question the ICDI, which is composed of 33 elements divided into 5 sections (as Chart 1). Thus, the existence of each of these elements has been verified, assigning value 1 (one) when it is identified on the company website or 0 (zero) otherwise.

With regard to risk, the proxies used were: Market-to-Book (MB), which measures the asymmetry of information from the future expectations of shareholders regarding investments (Diamond \& Verrecchia, 1991); Volatility, representing the changes in prices of the company's shares (Martins \& Paulo, 2014), taking the logarithm of the change in share price, day by day, closing at the end of 260 days the annual standard deviation; Intangibility, because the information asymmetry tends to be higher in companies that have a higher volume of intangible assets (Kang \& Gray, 2011); and Beta, that corresponds to the systematic risk part that cannot be diversified (Martins \& Paulo, 2014), measured with monthly data of the last 5 years.

To measure the return of the companies, it was also used as proxies: ROA, identifying how much return each asset generated for the company (Love, 2011); ROE, indicating how much return a company generated compared to the capital invested in it by its shareholders (Love, 2011); TRS, representing the ability the company has to generate shareholder value (Perez, 1995); and RC, since the improvement of the disclosure reduces the cost of third part capital, which represents a return to the lender (Verrecchia, 2001; Botosan \& Plumlee, 2002). All data were obtained in the Thompson Reuters database, and their calculations are summarized in Chart 1.

\section{(Chart 1)}

DESCRIPTION OF THE EXPLANATORY VARIABLES

\begin{tabular}{llll}
\hline Variables & Calculation & $\begin{array}{c}\text { Expected } \\
\text { Relationship }\end{array}$ & Reference \\
\hline $\begin{array}{l}\text { Market-to- } \\
\text { Book }\end{array}$ & $M B_{i t}=M V_{i t} / B V_{i t}$ & Negative & $\begin{array}{l}\text { Clarke and Shastri (2000); Diamond } \\
\text { and Verrecchia (1991). }\end{array}$ \\
\hline
\end{tabular}

(continue) 


\section{(Chart 1 (conclusion))}

\section{DESCRIPTION OF THE EXPLANATORY VARIABLES}

\begin{tabular}{|c|c|c|c|}
\hline Variables & Calculation & $\begin{array}{c}\text { Expected } \\
\text { Relationship }\end{array}$ & Reference \\
\hline Volatility & Volat $_{i t}=\sqrt{\sum \frac{\left(S_{i}-S_{m}\right)^{2}}{n \chi P P A}}$ & Negative & $\begin{array}{l}\text { Halov and Heider (2011); Murcia } \\
\text { et al. (2011); Martins and Paulo } \\
\text { (2014). }\end{array}$ \\
\hline Intangibility & $I N T_{i t}=I A_{i t} / T A_{i t}$ & Negative & $\begin{array}{l}\text { Barth and Kasznik (1999); Kang } \\
\text { and Gray (2011). }\end{array}$ \\
\hline Beta & $\beta_{i}=\frac{\operatorname{cov}\left(\left(R_{i t}\right),\left(R_{m t}\right)\right.}{\sigma^{2}\left(R_{m t}\right)}$ & Negative & $\begin{array}{l}\text { Amorim (2010); Martins } \\
\text { (2012). }\end{array}$ \\
\hline $\begin{array}{l}\text { Return on } \\
\text { Asset }\end{array}$ & $R O A_{i t}=N P_{i t} / T A_{(i t-1)}$ & Positive & \multirow{2}{*}{$\begin{array}{l}\text { Barber and Lyon (1996); Ettredge } \\
\text { et al. (2002); Lefort (2005); Leal } \\
\text { - and Carvalhal-da-Silva (2005); } \\
\text { Bollen et al. (2006); Gandia (2008); } \\
\text { Garay et al. (2013). }\end{array}$} \\
\hline $\begin{array}{l}\text { Return on } \\
\text { Equity }\end{array}$ & $R O E_{i t}=N P_{i t} /\left(E_{(i t-1)}-N P_{i t}\right)$ & Positive & \\
\hline $\begin{array}{l}\text { Total } \\
\text { Return to } \\
\text { Shareholders }\end{array}$ & $T R S_{i t}=\frac{D i v_{i t-1}}{P_{i t-1}}+\frac{P_{i t}-P_{i t-1}}{P i_{t-1}}$ & Positive & $\begin{array}{l}\text { Ross, Westerfield and Jaffe (2002); } \\
\text { Perez (1995). }\end{array}$ \\
\hline $\begin{array}{l}\text { Return to } \\
\text { Creditors }\end{array}$ & $R C_{i t}=I E_{i t} / O L_{i t}$ & Positive & $\begin{array}{l}\text { Botosan and Plumlee (2002); } \\
\text { Hail (2002); Verrecchia } \\
\text { (2001). }\end{array}$ \\
\hline
\end{tabular}

Notes: MV stands for market value; BV stands for book value; Si is the logarithm of share price; Sm is the average of $S ; ; n$ is the number of days; PPA is the trading amount in the period; IA stands for intangible asset; TA stands for total assets; Ri represents the return of share; Rm is the market return; NP stands for net profit; $E$ refers to liquid equity; Div is dividends; $P$ is the share price; IE stands for interest expenses; and OL stands for onerous liability.

Source: Elaborated by the authors.

Whereas external factors can affect the relationship between disclosure, risk and return, control variables were defined that make up the analyzed model based on Lefort (2005) and Garay et al. (2013), as follows: the issue of American Depository Receipt (ADR), the company's size, market liquidity of its shares and the country of the company.

The dummy issue of ADR is based on the fact that the regulation imposed on the US market demands for companies to disclose a greater amount of information to the public than the ones of Latin American markets (Garay et al., 2013), leading companies to have a higher degree of disclosure to 
companies that only trade locally. The company size was considered as larger firms tend to have higher degree of disclosure, since the cost of preparation is proportionally smaller than for smaller companies (Ettredge et al., 2002, Geerings et al., 2003; Gandia, 2008). This variable was represented by a dummy that took value 1 (one) when the total assets amount of company was greater than or equal to the median of the sample for each country separately, and 0 (zero) otherwise.

In terms of liquidity, it was considered that companies whose shares are most traded in the market tend to have higher disclosure, because it is assumed that their capital is pulverized among a greater number of shareholders (Botosan \& Plumlee, 2002; Dantas et al., 2005). In this study, liquidity was identified by the average trading volume of shares. Finally, it was considered as a dummy the country where each company operates since the protection of shareholders can vary between countries (La Porta et al., 1998).

\subsection{Regression models}

To estimate the regression in samples with censored dependent variable, the Minimum method Square Ordinaries (OLS) cannot be used, since the parameters may become biased and inconsistent due to the absence of information of some observations or because the censorship of the observed data (Long, 1997). For this reason, estimates were made by Tobit models, whose base is OLS, but it assumes a normal distribution truncated or censored, making it more efficient to estimate the relationship between a truncated dependent variable or censured and other explanatory variables, as Equation 1.

$$
\begin{array}{r}
\operatorname{ICDI}_{i t}=\gamma_{1}-\gamma_{2} M B_{i t-1}-\gamma_{3} \text { Volat }_{i t-1}-\gamma_{4} I_{N T_{i t-1}}-\gamma_{5} \text { Beta }_{i t-1}+\gamma_{6} R O A_{i t-1}+\gamma_{7} R O E_{i t-1} \\
-\gamma_{8} T_{i t S_{i t-1}}-\gamma_{9} R C_{i t-1}+\gamma_{10} A D R_{i t-1}+\gamma_{11} \operatorname{SIZE}_{i t-1}+\gamma_{12} L I Q_{i t-1}+u_{i t}
\end{array}
$$

Where, for every company $i$ in the period $t, \gamma_{1}, \ldots, n$ are the estimated parameters, $M B_{i t-1}$ is the Market-to-Book index, Volat ${ }_{i t-1}$ is the volatility of the most negotiated shares, $I N T_{i t-1}$ is the intangibility, Beta $_{i t-1}$ the risk beta, $R O A_{i t-1}$ is the return on asset, $R O E_{i t-1}$ is the return on equity, $R T A_{i t-1}$ is the total return to shareholders, $R C_{i t-1}$ is the return to creditors, $A D R_{i t-1}$ is the issue of American Depository Receipts, $S_{Z Z E_{i t-1}}$ is the company size measured by the logarithm of total asset, $L I Q_{i t-1}$ is the share liquidity in the stock market measured by the logarithm of the average negotiation volume of the most traded share and $u_{+}$is the error term. Thus, the models were estimated with the available data for each variable. 


\section{RESULTS}

\subsection{Descriptive analysis}

The results of the index data collection for each of the 33 ICDI items are shown in Table 1. In Section I, there was the highest percentage of compliance with the disclosure items $(79.5 \%)$ considering the sample as a whole. The item that had the lowest average percentage of disclosure was the "Environmental and/or social reports". A possible explanation for this is that this report is relatively younger than the other traditional financial reports listed in this section.

\section{(Table 1) \\ INTERNET-BASED CORPORATE DISCLOSURE INDEX (ICDI), PER COUNTRY (\%) - 2014}

\begin{tabular}{lccccc}
\hline Items & Argentina & Brazil & Chile & Mexico & Total \\
\hline Panel A: Section I & & & & & \\
\hline 1. Balance Sheet & 71.6 & 96.4 & 91.4 & 90.2 & 91.4 \\
2. Balance Sheet for previous years & 71.6 & 96.1 & 86.1 & 87.9 & 89.6 \\
3. Income Statement & 70.4 & 96.4 & 91.4 & 90.2 & 91.3 \\
4. Income Statement for previous years & 70.4 & 96.1 & 86.1 & 87.9 & 89.4 \\
5. Interim reports and periodicals & 63.0 & 95.5 & 70.1 & 90.2 & 84.8 \\
6. Explanatory notes & 69.1 & 96.4 & 91.4 & 90.2 & 91.2 \\
7. Cash Flow Statement & 65.4 & 96.4 & 90.9 & 89.4 & 90.5 \\
8. Cash Flow Statement for previous years & 65.4 & 96.1 & 86.1 & 87.1 & 88.8 \\
9. Environmental and/or social reports & 21.0 & 24.3 & 31.0 & 37.1 & 27.8 \\
10. Corporate report for previous years & 58.0 & 32.4 & 86.1 & 48.5 & 51.2 \\
11. Financial data time series & 69.1 & 95.5 & 85.0 & 87.9 & 88.8 \\
12. Selective accounting data & 44.4 & 66.2 & 83.4 & 73.5 & 69.4 \\
\hline \multicolumn{1}{c}{ Section I Mean } & 61.6 & 82.3 & 81.6 & 80.0 & 79.5 \\
\hline Panel B: Section II & & & & & \\
\hline 13. Press Release & 54.3 & 86.0 & 74.9 & 78.8 & 78.6 \\
14. Financial calendar & 17.3 & 66.2 & 13.9 & 29.5 & 41.6 \\
15. Current stock market price & 22.2 & 53.9 & 34.8 & 45.5 & 44.5 \\
16. Organizational structure & 40.7 & 56.4 & 84.5 & 37.9 & 58.3 \\
\hline & & & & & (continue)
\end{tabular}




\section{(Table 1 (conclusion)) \\ INTERNET-BASED CORPORATE DISCLOSURE INDEX (ICDI), PER COUNTRY (\%) - 2014}

\begin{tabular}{|c|c|c|c|c|c|}
\hline Items & Argentina & Brazil & Chile & Mexico & Total \\
\hline \multicolumn{6}{|l|}{ Panel B: Section II } \\
\hline 17. Composition of the board of directors & 46.9 & 76.0 & 90.4 & 62.9 & 74.0 \\
\hline 18. External links of interest to investors & 32.1 & 31.8 & 43.9 & 28.0 & 34.2 \\
\hline 19. Updated information every 24 hours & 17.3 & 53.4 & 15.0 & 47.0 & 39.1 \\
\hline Section II Mean & 32.8 & 60.5 & 51.0 & 47.1 & 52.9 \\
\hline \multicolumn{6}{|l|}{ Panel C: Section III } \\
\hline 20. Links for its accounting information & 67.9 & 96.1 & 90.4 & 89.4 & 90.5 \\
\hline 21. Annual reports in PDF & 64.2 & 96.1 & 90.4 & 90.2 & 90.2 \\
\hline 22. Processable financial data & 2.5 & 42.5 & 9.6 & 4.5 & 23.5 \\
\hline 23. Financial data in XBRL format & 0.0 & 0.0 & 0.5 & 0.8 & 0.3 \\
\hline 24. Web page in more than one language & 61.7 & 70.7 & 35.3 & 76.5 & 62.0 \\
\hline 25. Web page has its own search engine & 34.6 & 79.1 & 47.1 & 44.7 & 60.4 \\
\hline 26. Web page allows cookies & 14.8 & 44.4 & 3.7 & 33.3 & 29.3 \\
\hline Section III Mean & 35.1 & 61.3 & 39.6 & 48.5 & 50.9 \\
\hline \multicolumn{6}{|l|}{ Panel D: Section IV } \\
\hline $\begin{array}{l}\text { 27. Web page offers an email address } \\
\text { exclusively for investors }\end{array}$ & 24.7 & 72.1 & 38.5 & 58.3 & 56.3 \\
\hline $\begin{array}{l}\text { 28. Shareholders emails can be provided } \\
\text { for the company's directory }\end{array}$ & 53.1 & 76.3 & 51.3 & 46.2 & 62.4 \\
\hline 29. Has a FAQs section & 11.1 & 46.6 & 16.6 & 22.7 & 31.3 \\
\hline $\begin{array}{l}\text { 30. Allows the investor to request } \\
\text { additional information }\end{array}$ & 77.8 & 76.0 & 90.4 & 43.9 & 74.1 \\
\hline Section IV Mean & 41.7 & 67.7 & 49.2 & 42.8 & 56.0 \\
\hline \multicolumn{6}{|l|}{ Panel E: Section V } \\
\hline $\begin{array}{l}\text { 31. Allows real time participation in } \\
\text { meetings of the board of directors }\end{array}$ & 16.0 & 53.4 & 9.6 & 28.8 & 34.3 \\
\hline $\begin{array}{l}\text { 32. Offers access to document (audio or } \\
\text { video) of previous meetings }\end{array}$ & 21.0 & 94.7 & 79.7 & 28.0 & 71.5 \\
\hline $\begin{array}{l}\text { 33. Offers access to presentations (audio } \\
\text { or video) of previous meetings }\end{array}$ & 21.0 & 58.4 & 31.6 & 42.4 & 45.0 \\
\hline Section II Mean & 19.3 & 68.8 & 40.3 & 33.1 & 50.3 \\
\hline Total ICDI Mean & 43.6 & 70.2 & 58.5 & 57.6 & 62.3 \\
\hline
\end{tabular}

Source: Elaborated by the authors. 
In Sections II and III (52.9\% and 50.9\%) we to note that the items that showed the lowest averages are related to the exploitation of the Internet as a disclosure tool. The results of Sections IV and V (56.0\% and 50.3\%) were strongly supported by Brazilian companies, since they represent $47.0 \%$ of the total sample and complied with more than $60.0 \%$ of the items in each section. Apart from Brazilian companies, the average of Section IV would be reduced to $44.6 \%$ and in Section V to $30.9 \%$.

Considering all 33 items, the companies in the sample, on average, attended $62.3 \%$ of the total disclosure, a little more than 20 percentage points than the amount observed by Garay et al. (2013) in 2010 (41.0\%). In Garay et al. (2013), Brazil has also obtained the lead in the ICDI (55.0\%), and was followed by Mexico (50.0\%), Chile (38.0\%) and to a lesser degree of disclosure by Argentina (34.0\%). In addition, it was performed an analysis of the ICDI results by sector, but they did not identify strong differences between them.

Additionally, an analysis of the ICDI results was performed considering the selected control variables. About $18.3 \%$ of the sample have ADRs and, as expected, the average ICDI of them $(76.4 \%)$ is higher than those that have not $(59.1 \%)$. Making an analysis by company size, larger companies have released more information $(72.5 \%)$ than smaller ones $(54 \%)$, as expected in the literature (Geerings et al., 2003; Bollen et al., 2006). This confirms the importance of considering the size as a control variable in this analysis.

This same analysis was performed considering the share liquidity of the companies. As identified in the literature (Vanstraelen, Zarzerski, \& Robb, 2003; Bollen et al., 2006), companies with greater liquidity in each country reported higher degree of compliance with ICDI items $(76.4 \%)$, indicating better disclosure than other companies (64.0\%). Table 2 shows the descriptive statistics of the risk, return and control variables.

\section{(Table 2)}

DESCRIPTIVE STATISTICS OF INDEPENDENT AND CONTROL VARIABLES - 2014

\begin{tabular}{ccccccc}
\hline Variables & Mean & Media & $\begin{array}{c}\text { Standard } \\
\text { Deviation }\end{array}$ & Min & Max & Observations \\
\hline $\begin{array}{ccccc}\text { Market-to- } \\
\text { Book* }\end{array}$ & 0.9 & 0.5 & 3.3 & 0.0 & 76.3 & 669 \\
Volatility* $^{37.8}$ & 33.2 & 30.4 & 0.0 & 309.3 & 655 \\
\hline
\end{tabular}




\section{(Table 2 (conclusion)) \\ DESCRIPTIVE STATISTICS OF INDEPENDENT AND CONTROL VARIABLES - 2014}

\begin{tabular}{lcccccc}
\hline \multicolumn{1}{c}{ Variables } & Mean & Media & $\begin{array}{c}\text { Standard } \\
\text { Deviation }\end{array}$ & Min & Max & Observations \\
\hline Intangibility** & 7.8 & 1.3 & 15.4 & -7.0 & 89.1 & 594 \\
Beta* & 0.6 & 0.5 & 0.5 & -2.3 & 2.8 & 572 \\
\hline ROA $^{* \star}$ & -3.4 & 3.5 & 133.2 & -3294.3 & 291.9 & 705 \\
ROE $^{* *}$ & 11.7 & 11.0 & 97.1 & -1691.3 & 862.1 & 705 \\
TRS $^{* *}$ & 19.1 & -7.2 & 172.4 & -89.5 & 2783.9 & 567 \\
RC** & 146.5 & 7.6 & 2738.7 & -1.3 & 64112.7 & 551 \\
\hline Size & 20.4 & 20.6 & 2.3 & 8.4 & 27.0 & 720 \\
Liquidity & 12.0 & 12.4 & 3.1 & 0.0 & 19.8 & 480 \\
ADR & 0.2 & 0.0 & 0.4 & 0.0 & 1.00 & 758 \\
\hline
\end{tabular}

Notes: The variables that have * as reported as index and the ones that have ** in percentage.

Source: Elaborated by the authors.

Among the risk variables, the volatility presented the highest average (37.8), followed by Intangibility (7.8\%). As for the return, it can be note that the highest average was the return to creditors (146.5\%), followed by Total Return to Shareholders (19.1\%). Nonetheless, it can be seen that the standard deviations of all variables are high, which is reflected in the gaps between the minimum and maximum values. In the last column, it was highlighted the number of observations for each variable, varying according to data availability.

\subsection{Relationship analysis}

To assess the degree of relationship between the variables, it was analyzed multicollinearity possible indicia by correlation matrix and the variance inflation factor (VIF). Considering the absence of normal distribution in the variables, the Spearman correlation showed that the highest correlation was observed between ROA and ROE (0.675), indicating no multicollinearity problem. The latter was ratified by the maximum VIF found (1.36). It can be observed that the chi-square statistic of the estimated model is significant at $1 \%$ level (115.90), indicating its robustness to the analysis of pre-established relations, which is ratified by its Log Likelihood -1,575.08. The significance of the constant indicates that there are other variables not included in the model, which can affect the ICDI's relations with the risk and the return of the companies, according to Table 3. 
As regards the analysis of ICDI's relationship with the risk and the return of the companies, to our knowledge, no previous study identified such a relationship in Latin America, even in Brazil. On the one hand, this indicates the degree of originality of this study and, on the other, makes it difficult to compare their results. Thus, the findings are related to correlated studies, especially in the case of companies' disclosure (general).

In its results, the marginal effects of the ICDI can only be verified for three of the eight proxies for risk and return, as showed statistically significant relationships. Among them, the strongest relationship with the ICDI was the Market-to-Book ratio (-2.01), indicating that the improvement of company's disclosure tends to generate a reduction in the information risk. As this proxy is able to capture the information asymmetry and market expectation of company's appreciation or depreciation, it was expected a negative relationship between this variable and the ICDI (Aslan, Easley, Hvidkjaer, \& O'Hara, 2001), which was confirmed in this study.

\section{(Table 3)}

TOBIT REGRESSION BETWEEN ICDI AND RISK AND RETURN VARIABLES - 2014

\begin{tabular}{|c|c|c|c|}
\hline Variable & Coefficient & Standard Error & Z Statistic \\
\hline Constant & 59.44 & 2.32 & $25.56^{\star \star \star}$ \\
\hline Market-to-Book & -2.01 & 1.06 & $-1.88^{\star}$ \\
\hline Volatility & 0.02 & 0.03 & 0.65 \\
\hline Intangibility & 0.14 & 0.05 & $2.59 * \star \star$ \\
\hline Beta & 2.16 & 1.86 & 1.16 \\
\hline $\mathrm{ROA}$ & 0.11 & 0.09 & 1.31 \\
\hline ROE & 0.00 & 0.01 & 0.20 \\
\hline TRS & -0.00 & 0.00 & -1.56 \\
\hline $\mathrm{RC}$ & -0.01 & 0.00 & $-3.16^{\star \star \star}$ \\
\hline ADR & 5.94 & 2.08 & $2.85^{\star \star \star}$ \\
\hline Size & 6.43 & 2.02 & $3.17^{\star \star \star}$ \\
\hline Liquidity & 8.22 & 2.15 & $3.82^{\star * \star}$ \\
\hline Chi-Square & 115.90 & p-value & $0.000^{* * \star}$ \\
\hline Log. Like. & -1575.08 & Akaike & 3176.16 \\
\hline Schwarz & 3227.14 & Hannan-Quinn & 3196.40 \\
\hline
\end{tabular}

Notes: ${ }^{\star \star \star}$ is significant at $1 \%$ and ${ }^{*}$ at $10 \%$. 
Intangibility presented a positive $(0.14)$ and significant relation with the ICDI, contrary to expectations. This result may be related to the additional outreach effort Latin American companies with higher intangibles have to create greater confidence in investors and attract more capital (Gandia, 2003; Lefort, 2005; Garay et al., 2013). As Beta and Volatility have not presented significant relationships, it was not possible to make inferences about its relations with companies' disclosure in the internet.

Among the return variables, only the return to creditors $(-0.01)$ showed a significant relationship with the ICDI, suggesting that for the total sample, the disclosure of companies did not affect company's return on total assets (ROA) for equity (ROE) or shareholders (TRS). The relation found between the ICDI and RC was negative, as expected since, based on the literature, the higher degree of disclosure leads to a lower cost of debt, which leads the lender to require lower return to their capital (Verrecchia, 2001; Botosan \& Plumlee, 2002).

As for the control variables (ADR, Size and Liquidity), they showed positive and significant relationships, as expected, indicating that they have the ability to change the observed relationships. To analyze the influence of each control variable on the sample in question were carried out estimations for the set of proxies (risk and return), whose results are presented in Tables 4 and 5 .

Table 4 gathers the results for analysis of ICDI with the risk proxies, considering each control variable. With control by ADR, it is clear that Intangibility and Beta maintained statistical significance, but their relations are reversed to negative $(-0.21$ and -12.39$)$, indicating that the disclosure on the Internet was effective in reducing the risk only in companies with ADRs traded on the New York Stock Exchange (NYSE). This result is in line with the literature, since it is expected that companies that do not issue ADRs only disclose information in compliance with the requirements of national legislation, which are lower than those required by the US market (Lefort, 2005; Garay et al., 2013; Martins \& Paulo, 2014).

With regard to the control based on companies' size, it was observed that among the companies that have total assets smaller than the median of their country of origin, there was a positive and significant relationship of the ICDI with Intangibility (0.17) and Beta (7.65), suggesting that with the increase in the disclosure, these variables also expand. Among the companies that have total assets greater than the median of their country, only MB (2.88) showed a significant relationship, however positive.

This result goes against the literature, which expects that larger companies use the internet more intensively to disclore information than smaller 
companies and thus reduce their risk (Ettredge et al., 2002; Geerings et al., 2003; Bollen et al., 2006; Gandia, 2008). However, considering that larger companies disclose more information and, therefore, attract a larger number of investors, increasing the liquidity of its assets, this can lead to a reduction in volatility and change the sign of the relationship between disclosure and Market-to-Book (Diamond \& Verrecchia, 1991).

\section{(Table 4)}

\section{ICDI REGRESSION X RISK VARIABLES WITH CONTROL BY ADR, TAM AND LIQ - 2014}

\begin{tabular}{|c|c|c|c|c|c|c|}
\hline \multirow{2}{*}{ Variable } & \multicolumn{2}{|c|}{ Control by ADR } & \multicolumn{2}{|c|}{ Control by Size } & \multicolumn{2}{|c|}{ Control by Liquidity } \\
\hline & Coefficie. & Z Stat. & Coefficie. & Z Stat. & Coefficie. & Z Stat. \\
\hline Constant & 59.51 & $31.47^{\star \star \star}$ & 55.50 & $24,74^{\star \star \star}$ & 57,92 & $30,56^{\star \star \star}$ \\
\hline Market-to-Book & -1.36 & -1.60 & -1.45 & $-1,47$ & $-1,90$ & $-2,07^{\star \star}$ \\
\hline Volatility & -0.01 & -0.41 & 0.02 & 0,59 & 0,02 & 0,73 \\
\hline Intangibility & 0.26 & $4.10^{\star \star \star}$ & 0.17 & $1,89^{\star}$ & 0,21 & $2,75^{\star \star \star}$ \\
\hline Beta & 9.44 & $5.36^{\star \star \star}$ & 7.65 & $2,92^{\star \star \star}$ & 6,43 & $3,06^{\star \star \star}$ \\
\hline $\mathrm{D}(\mathrm{ADR})$ & 15.37 & $2.82^{\star \star \star}$ & & & & \\
\hline $\begin{array}{l}\text { D*Market- } \\
\text { to-Book }\end{array}$ & 2.24 & 1.04 & & & & \\
\hline D*Volatility & 0.12 & 1.36 & & & & \\
\hline D*Intangibility & -0.21 & $-1.70^{\star}$ & & & & \\
\hline D*Beta & -12.39 & $-2.88^{\star \star \star}$ & & & & \\
\hline $\mathrm{D}($ Size) & & & 10.63 & $2,89 * \star \star$ & & \\
\hline $\begin{array}{c}\text { D*Market- } \\
\text { to-Book }\end{array}$ & & & 2.88 & $1,80^{*}$ & & \\
\hline D*Volatility & & & 0.08 & 1,30 & & \\
\hline D*Intangibility & & & -0.00 & $-0,00$ & & \\
\hline D*Beta & & & -4.77 & $-1,40$ & & \\
\hline D(Liquidity) & & & & & 20,64 & $4,21^{\star \star \star}$ \\
\hline $\begin{array}{l}\text { D*Market-to- } \\
\text { Book }\end{array}$ & & & & & 1,36 & 0,80 \\
\hline D*Volatility & & & & & 0,03 & 0,43 \\
\hline D*Intangibility & & & & & $-0,13$ & $-1,24$ \\
\hline D*Beta & & & & & $-10,18$ & $-2,75$ \\
\hline
\end{tabular}

(continue) 


\section{(Table 4 (conclusion)) \\ ICDI REGRESSION X RISK VARIABLES WITH CONTROL BY ADR, TAM AND LIQ - 2014}

\begin{tabular}{|c|c|c|c|c|c|c|}
\hline \multirow{2}{*}{ Variable } & \multicolumn{2}{|c|}{ Control by ADR } & \multicolumn{2}{|c|}{ Control by Size } & \multicolumn{2}{|c|}{ Control by Liquidity } \\
\hline & Coefficie. & Z Stat. & Coefficie. & Z Stat. & Coefficie. & Z Stat. \\
\hline Chi-Square & $96.70^{\star \star \star}$ & & $118.56^{\star \star \star}$ & & $128.06^{\star \star \star \star}$ & \\
\hline Log. Like. & -2113.01 & & -2104.05 & & -2100.27 & \\
\hline Schwarz & 4294.16 & & 4276.23 & & 4268.69 & \\
\hline Akaike & 4248.02 & & 4230.09 & & 4222.55 & \\
\hline Hannan-Quinn & 4266.14 & & 4248.21 & & 4240.67 & \\
\hline
\end{tabular}

Notes: *** is significant at $1 \%$, ** at $5 \%$ and * at $10 \%$.

\section{Source: Elaborated by the authors}

When the control is performed based on the liquidity of shares, it was found that among companies with lower volume of liquidity the Intangibility (0.21) and beta (6.43) also showed a positive and significant relationship with ICDI, contrary to expectations. In addition, Market-to-Book (-1.90) showed a negative and significant relationship with the ICDI, indicating that the higher the disclosure, the lower the risk would be captured by this indicator. In addition, the greatest value of the logarithm Likelihood (-2100.27) and the lowest values of the adjustment criteria (Schwarz $=4268.49$, Akai$\mathrm{ke}=4222.55$ and Hannan-Quinn $=4240.67$ ), it is observed that the model with better adjustment was the one with the liquidity control.

These results are in line with previous studies, which claim that it is reasonable to expect that stocks with higher liquidity indicate a higher spread capital, which, in turn, demands higher levels of disclosure (Botosan \& Plumlee, 2002; Dantas et al., 2005). Despite the control by liquidity present a statistical significance, all the results obtained from companies with liquidity above the median of their country were not statistically significant, suggesting that, in the 2014 sample, there is no direct relationship between risk proxies and disclosure of information in the internet among companies with more liquid stocks.

It is noteworthy that in the three estimates considering the dummy variables for both risk in Table 4, as the three estimates with the controls for the return proxies in Table 5, the models showed a significance of $1 \%$ in the chi-square statistic test indicating that the analysis of the predetermined relationships have strength. 


\section{(Table 5)}

ICDI REGRESSION X RETURN VARIABLES WITH CONTROL BY ADR, TAM AND LIQ - 2014

\begin{tabular}{|c|c|c|c|c|c|c|}
\hline \multirow{2}{*}{ Variable } & \multicolumn{2}{|c|}{ Control by ADR } & \multicolumn{2}{|c|}{ Control by Size } & \multicolumn{2}{|c|}{ Control by Liquidity } \\
\hline & Coefficie. & Z Stat. & Coefficie. & Z Stat. & Coefficie. & Z Stat. \\
\hline Constant & 65.50 & $58.57^{\star \star \star}$ & 61.48 & $44,71^{\star \star \star}$ & 63,78 & $54,27^{\star \star \star}$ \\
\hline $\mathrm{ROA}$ & 0.09 & 1.26 & 0.11 & 1,63 & 0,00 & 0,02 \\
\hline ROE & 0.01 & 0.95 & 0.01 & 0,66 & $-0,00$ & $-0,20$ \\
\hline TRS & -0.00 & -1.53 & -0.04 & $-3,04^{\star \star \star}$ & $-0,03$ & $-2,65^{\star \star \star}$ \\
\hline $\mathrm{RC}$ & 0.00 & 0.51 & 0.00 & 0,88 & $-0,01$ & $-2,27^{\star \star}$ \\
\hline$D(A D R)$ & 11.41 & $5.09 * \star \star$ & & & & \\
\hline $\mathrm{D} * \mathrm{ROA}$ & 0.21 & 0.89 & & & & \\
\hline $\mathrm{D} * \mathrm{ROE}$ & -0.02 & -0.57 & & & & \\
\hline$D^{*}$ TRS & 0.00 & 0.18 & & & & \\
\hline$D^{*} R C$ & -0.00 & -0.31 & & & & \\
\hline $\mathrm{D}$ (Size) & & & 13.54 & $6,96 * \star \star$ & & \\
\hline$D^{*} \mathrm{ROA}$ & & & -0.14 & $-0,79$ & & \\
\hline$D^{*} \mathrm{ROE}$ & & & -0.01 & $-0,49$ & & \\
\hline D*TRS & & & 0.03 & $2,55^{\star \star}$ & & \\
\hline $\mathrm{D*} R \mathrm{C}$ & & & -0.01 & $-2,46^{\star \star}$ & & \\
\hline D(Liquidity) & & & & & 11,31 & $5,53^{\star \star \star}$ \\
\hline $\mathrm{D}^{*} \mathrm{ROA}$ & & & & & 0,34 & $1,85^{\star}$ \\
\hline D*ROE & & & & & 0,00 & 0,29 \\
\hline D*TRS & & & & & 0,02 & 1,83 \\
\hline$D * R C$ & & & & & 0,01 & $2,29 * *$ \\
\hline Chi-Square & $41.76^{\star \star \star}$ & & $75.71^{\star \star \star}$ & & $88.92^{\star \star \star}$ & \\
\hline Log. Like. & -1984.27 & & -1969.24 & & -1963.64 & \\
\hline Schwarz & 4035.91 & & 4005.86 & & 3994.66 & \\
\hline Akaike & 3990.54 & & 3960.49 & & 3949.29 & \\
\hline Hannan-Quinn & 4008.41 & & 3978.36 & & 3967.16 & \\
\hline
\end{tabular}

Notes: ${ }^{\star \star *}$ is significant at $1 \%,{ }^{* \star}$ at $5 \%$ and * at $10 \%$.

\section{Source: Elaborated by the authors.}

Regarding the return of proxies, in Table 5, although the ADR dummy presented a statistical significance, the relationships found were not significant, suggesting that the dissemination of information over the Internet did 
not directly impact the return of companies in the sample considered. This result was also found in earlier papers (Ettredge et al., 2002; Bollen et al., 2006; Gandia, 2008).

Considering the size dummy, the TRS showed a significant relationship that turned positive with the inclusion of the dummy (0.03), which indicates that, for larger companies, information disclosure increase on the Internet extends the Total Return to shareholders, in line with the literature (Verrecchia, 2001). In addition, among the largest companies, RC (-0.01) showed a negative and significant relationship, as expected (Verrecchia, 2001; Botosan \& Plumlee, 2002).

In the estimates including the dummy liquidity, among the least liquid companies it can be observed a negative and significant relationship of ICDI with TRS (-0.03) and RC (-0.01), which means that a higher level of disclosure would lead to a reduction in the return to creditors and shareholders. However, when considering only the most liquid companies, these relationships have changed and TRS (0.02) and RC (0.01) present positive and significant relationships with ICDI. This result shows that, based on these two proxies, only among companies with less liquidity the disclosure on the Internet was effective in reducing returns to shareholders and creditors, since the risk of these companies is reduced with greater disclosure, which is in line with the literature, that stands that companies with less liquid stocks get lower returns - the inverse is also true (Botosan \& Plumlee, 2002; Dantas et al., 2005). In addition, the model with control by liquidity again showed better adjustment, with a higher logarithm Likelihood (-1963.64) and minor criteria of Schwarz (3994.66), Akaike (3949.29) and Hannan-Quinn (3967.16).

To deepen the understanding of risk and return relationships in Latin America is very important to analyze them segregated by country. Table 6 shows the estimates considering the proxies for risk, with control by country. The dummy for the country Argentina presented significance in the regression with the risk proxies, however, showed a negative relationship, which means that when the company is located in Argentina, it implies a lower level of disclosure. With the inclusion of this dummy, Market-to-Book was the only variable that showed a statistically significant relationship with ICDI (-4.04), indicating that the increased disclosure tends to reduce the risk measured by this variable. The relationship found was in line with the literature, which states that greater disclosure has the ability to reduce the risk (Aslan et al., 2001). However, the other relationships were not significant.

Although the dummy for Brazil report a positive and significant relationship with ICDI, which indicates that the fact that the company is located 


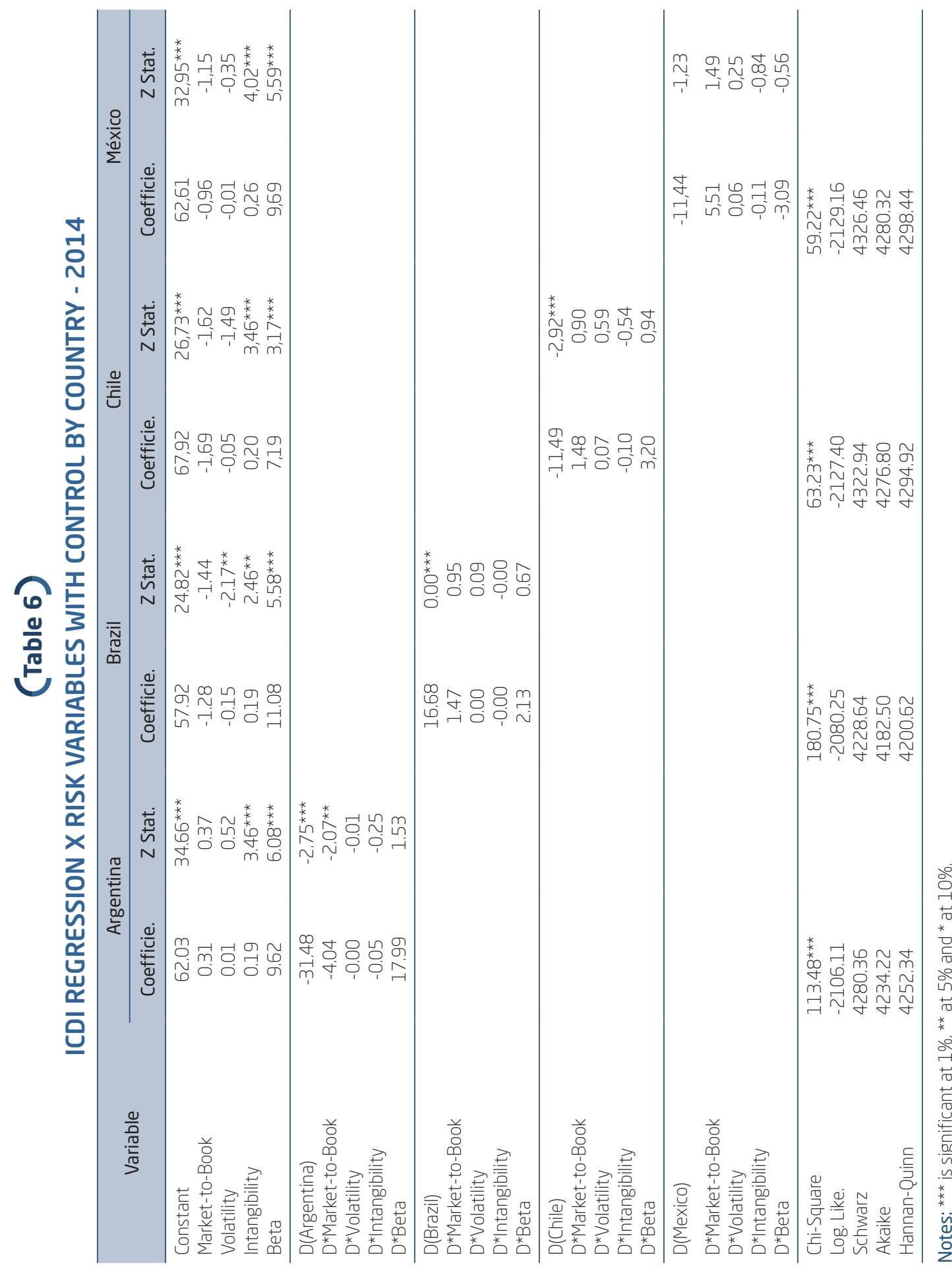


in Brazil implies greater disclosure on the Internet, when considered only Brazilian companies, statistical significant relationships are not found. Thus, one cannot say that an expansion of the disclosure on the Internet can reduce the risk of companies exclusively in Brazil. Like Argentina, Chile dummy showed a significant negative relationship with ICDI, but with its inclusion there was no statistical significant relationships, suggesting that the increased disclosure in Chilean companies do not have the power to reduce the risk of companies. This same result was found for Mexican companies, the fact that the company is based in Mexico does not influence the level of disclosure on the Internet.

It could be also verified that all models were significant by chi-square test, confirming its strength, and that the model estimated for Brazil showed better adjustment, with higher logarithm Likelihood (-2080.25) and minor information criteria of Schwarz (4228.64), Akaike (4182.50) and Hannan-Quinn (4200.62).

In Table 7 the estimation results are presented, on a consolidated basis, between the proxies for return and control by country. Despite the dummies for Argentina, Brazil and Chile maintain significant relationships with ICDI, none of the relationships found with the inclusion of the control for these countries presented a statistical significance. This implies that one cannot say that an increase in the dissemination of information between companies located in these three countries produces an increase in the return of the companies.

In the estimation that considers the control for Mexico, although the dummy did not present statistical significance, that is, the company's location in Mexico do not impact the level of disclosure, significant relationships were found. The ROA (0.60) showed a positive relationship, so as Mexican companies expand their degree of disclosure on the Internet, the return on assets also increases in line with the investigated literature (Ettredge et al., 2002; Bollen et al., 2006; Gandia, 2008).

In addition, the return to creditors showed a negative correlation (-1.71), in which a greater degree of disclosure would lead to a lower cost of debt and, consequently, lower returns to creditors (Verrecchia, 2001; Botosan \& Plumlee, 2002). Thus, as the vast majority of interactions with dummy by country, both for risk and return proxies, did not present statistical significance, it cannot be said that there are differences between countries, although Argentina and Chile have shown negative and significant relations with ICDI, Brazil a positive and significant and Mexico have not obtained significant relationship with ICDI.

Finally, it appears that all models were significant by chi-square test, confirming its strength, and that the model estimated for Brazil had the 


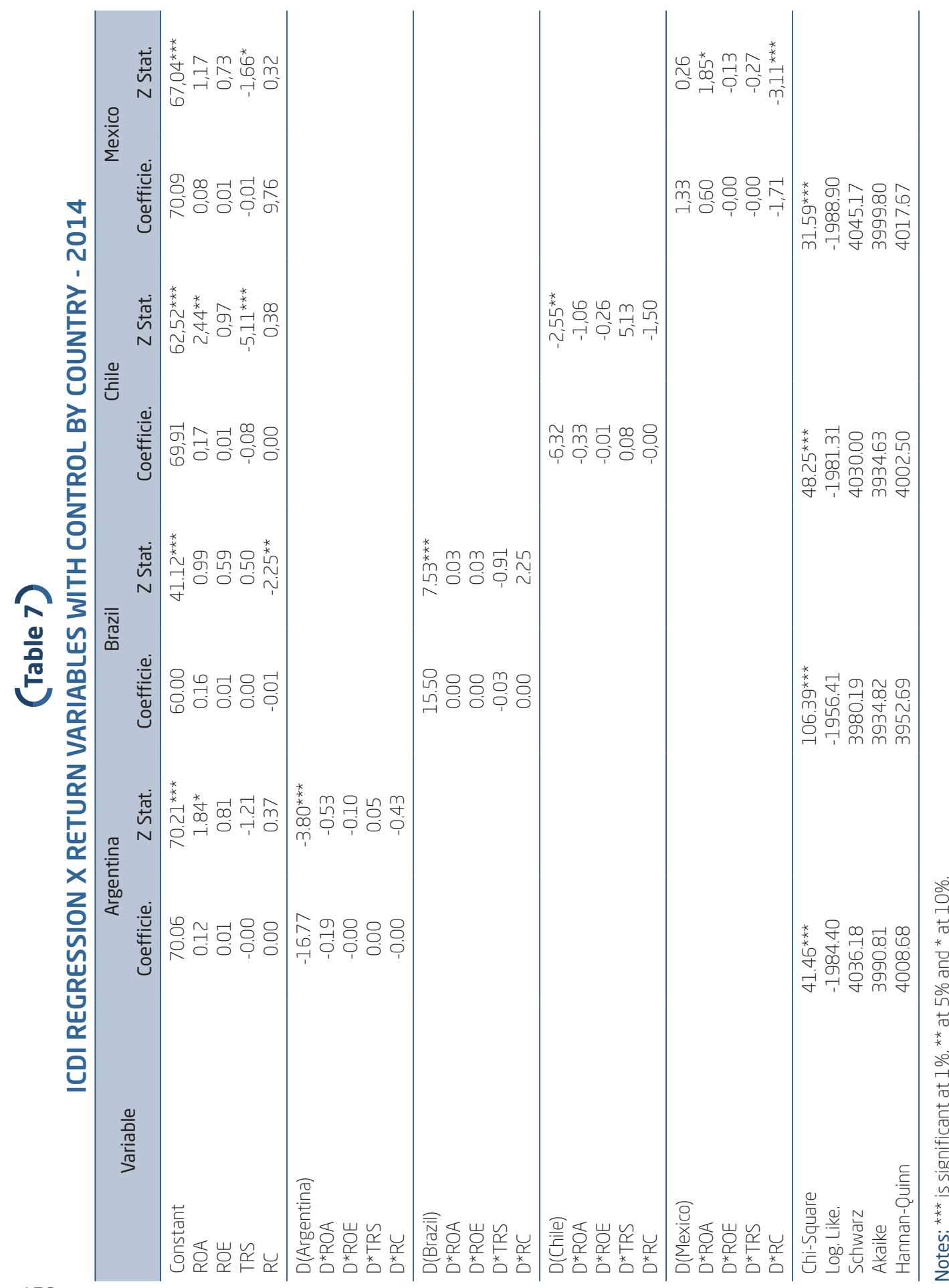


higher logarithm Likelihood (-1956.41) and the lowest information criteria of Schwarz (3980.19), Akaike (3934.82) and Hannan-Quinn (3952.69).

\section{FINAL CONSIDERATIONS}

It can be observed that to interfere effectively in relationships and minimize the risk the disclosure should be elevated to the accuracy of developed markets, such as the North American one, where it requires greater level of disclosure in the issuance of ADRs, which coincides with the studied literature. Additionally, the results suggest that the increased disclosure only has a positive impact on the return if the companies also present high liquidity in the trading of its shares. In this sense, there is a risk reduction among companies with greater disclosure and increased returns among the companies with higher liquidity, which confirms the need from companies an additional effort to disclose more and better information.

Among the key factors that may influence the relationship of disclosure with the risk and the return in Latin America, it is reasonable to assume that are the country risk and low legal protection of countries. Therefore, it is possible to consider that investors in this region may prefer more liquid stocks because they have higher possibility to unload their positions more quickly in instability or insecurity situations. This effect appears to be similar for all countries, because despite the different relationships found between the dummies by country and ICDI, it cannot be said that the disclosure effect shows significant differences between countries in the impact with the risk and the return of companies.

It is worth nothing that these results are limited to companies analyzed during the studied period. Therefore, they cannot be generalized, since they have limitations on the sample and the period, which are unique to this type of study. However, such limitations do not invalidate, considering their findings and their contributions, which are useful to the academia as they expand the isolated evidences on disclosure, risk and return, relating them to each other, providing deeper inferences in this discussion, besides being useful to the market, serving as a support to investors in their investment decisions in Latin American markets.

Finally, it stands out the limitations of the study, such as the inability to perform retroactive analysis when considering the Internet as a dissemination channel, because it does not have historical information on companies' websites. Yet, as future research, it stands out the important role of helping 
to build a database enabling comparative analysis of longer data series, expanding the vision of development of this disclosure tool and its impact on the risk and the return in this region.

\section{ANÁLISE DA RELAÇÃO ENTRE DISCLOSURE NA INTERNET, RISCO E RETORNO EM COMPANHIAS LATINO-AMERICANAS}

\section{RESUMO}

Objetivo: Este estudo buscou analisar as relações entre a disclosure de informações divulgadas na internet, o risco de informação e o retorno das empresas na América Latina.

Originalidade/lacuna/relevância/implicações: Este estudo se diferencia dos anteriores já que preenche uma lacuna na literatura ao relacionar uma medida de disclosure na internet com o risco e o retorno das empresas na América Latina, uma vez que nessa literatura só é possível identificar estudos que analisam tais variáveis de forma independente ou com relação a outros fatores.

Principais aspectos metodológicos: A amostra contou com 758 empresas listadas nas quatro principais bolsas latino-americanas (Argentina, Chile, Brasil e México) que tiveram seu nível de disclosure quantificado e verificadas as relações com o risco e o retorno por meio de regressões Tobit. Síntese dos principais resultados: Os resultados evidenciam que é possível observar que a emissão de ADR, o tamanho e a liquidez afetam as relações entre disclosure, risco e retorno. Ainda, que a disclosure na região tem avançado ao longo dos anos, com destaque para o Brasil. Porém, não foram identificadas diferenças significantes entre os países, ao ponto de impactar as relações com o risco e o retorno das empresas.

Principais considerações/conclusões: Suas principais contribuições são a ampliação das evidências sobre essas variáveis, relacionando-as entre si em mercados emergentes.

\section{PALAVRAS-CHAVE}

Disclosure. Índice. Informação. Mercado de capitais. América Latina. 


\section{ANÁLISIS DE LA RELACIÓN ENTRE LA DIVULGACIÓN EN INTERNET, RISCO Y RETORNO EN EMPRESAS DE AMÉRICA LATINA}

\section{RESUMEN}

Objetivo: Este estudio investiga la relación entre la divulgación de la información divulgada en Internet, el riesgo de información y retorno de las compañías en América Latina.

Originalidad/laguna/relevancia/implicaciones: Este estudio difiere de los anteriores, ya que llena un vacío en la literatura por relacionar una medida de divulgación en el Internet con el riesgo y el retorno de las empresas en América Latina, una vez que en esta literatura sólo es posible identificar estudios que analizan estas variables de forma independiente o con respecto a otros factores.

Principales aspectos metodológicos: Su muestra incluyó 758 empresas que figuran en los cuatro principales mercados de valores de América Latina (Argentina, Chile, Brasil y México) que tuvieron su nivel de disclosure cuantificada y verificadas las relaciones con el riesgo y el retorno a través de regresiones Tobit.

Síntesis de los principales resultados: Los resultados muestran que es posible observar que la emisión de ADR, el tamaño y la liquidez afectan las relaciones entre disclosure, riesgo y retorno. Además, la disclosure ha avanzado en la región en los últimos años, especialmente en Brasil. Sin embargo, no hubo diferencias significativas entre los países, hasta el punto de impactar las relaciones con el riesgo y el retorno de las empresas.

Principales consideraciones/conclusiones: Sus principales contribuciones son la expansión de evidencias sobre estas variables, relacionándolos entre sí en los mercados emergentes.

\section{PALABRAS CLAVE}

Disclosure. Índice. Información. Mercado de capitales. América Latina. 


\section{REFERENCES}

Aksu, M., \& Kosedag, A. (2006). Transparency and disclosure scores and their determinants in the Istanbul Stock Exchange. Corporate Governance - an International Review, 14(4), 277-296.

Amorim, A. L. G. C. (2010). Análise da relação entre a informação contábil e o risco sistemático. Tese de Doutorado, Universidade de São Paulo, São Paulo, Brasil.

Aslan, H., Easley, D., Hvidkjaer, S., \& O’Hara, M. (2001). The characteristics of informed trading: implications for assets pricing. Journal of Empirical Finance, 18(5), 782-801.

Barth, M. E. \& Kasznik, R. (1999). Share repurchases and intangible assets. Journal of Accounting and Economics, 28, 211-241.

Barber, B. M. \& Lyon, J. D. (1996). Detecting abnormal operating performance: the empirical power and specification of test statististics. Journal of Financial Economics, 41(3), 359-399.

Bollen, L., Hassink, H., \& Bozic, G. (2006). Measuring and explaining the quality of internet investor relations activities: a multinational empirical analysis. International Journal of Accounting Information System, 7(4), 273-98.

Botosan, C. A., \& Plumlee, M. (2002). A re-examination of disclosure level and the cost of equity capital. Journal of Accounting Research, 40(1), 21-40.

Bushman, R., Piotroski, J., \& Smith, A. (2004). What determines corporate transparency?. Journal of Accounting Research, 42(2), 207-252.

Bushman, R., \& Smith, A. (2001). Financial accounting information and corporate governance. Journal of Accounting and Economics, 32 (1), 237-333.

Clarke, J., \& Shastri, K. (2000). On information asymmetry metric. SSRN Working Paper. Retreived from http://papers.ssrn.com/sol3/papers.cfm? abstract_id=251938.

Chong, A., \& Lopez-de-Silanes, F. (2007). Investor protection and corporate governance: intra-firm evidence across Latin-America. Palo Alto: Stanford University Press.

Dantas, J. A. et al. (2005). A dualidade entre os benefícios do disclosure e a relutância das organizações em aumentar o grau de evidenciação. E\& $G$ Economia e Gestão, 5(11), 56-76.

Deller, D., Stubenrath, M., \& Weber, C. (1999). A survey on the use of the internet for investor relations in the USA, the UK and Germany. European Accounting Review, 8(2), 351-364. 
Diamond, D. W., \& Verrecchia, R. E. (1991). Disclosure, liquidity, and the cost of capital. The Journal of Finance, 46(4), 1325-1359.

Ettredge, M., Richardson, V. J., \& Scholz, S. (2002). Dissemination of information for investors at corporate websites. Journal of Accounting and Public Policy, 21 (4/5), 357-369.

Fama, E. F. (1970). Efficient capital markets: a review of theory and empirical work. The Journal of Finance, 25(2), 383-417.

Fama, E. F. (1991). Efficient capital markets: II. The Journal of Finance, 46(5), 1575-1617.

Feyitimi, O. (2014). The level of financial information disclosure and corporate attributes in developing economy. European Journal of Business and Management, 6(3), 176-188.

Gandia, J. L. (2003). Intangibles disclosure information on internet by multinational corporations. The International Journal of Digital Accounting Research, 3(5), 61-99.

Gandia, J. L. (2008). Determinants of internet-based corporate governance disclosure by Spanish listed companies. Emerald Online Information Review, $32(6), 791-817$.

Garay, U. et al. (2013). Internet-based corporate disclosure and market value: Evidence from Latin America. Emerging Market Review, 17(1), 160-168.

Garay, U., \& Gonzalez, M. (2008). Corporate governance and firm value: the case of Venezuela. Corporate Governance an International Review Journal, 16 (3), 194-209.

Geerings, J., Bollen, L., \& Hassink, H. (2003). Investor relations on the internet: a survey of the Euronext zone. European Accounting Review, 12 (3), 567-579. Hail, L. (2002). The impact of voluntary corporate disclosures on the exante cost of capital for Swiss firms. The European Accounting Review, 11(4), 741-773.

Halov, N. \& Heider, F. (2011). Capital structure, risk and asymmetric information. Quarterly Journal of Finance, 1(4), 767-809.

Hermalin, B., \& Weisbach, M. (2012). Information disclosure and corporate governance. Journal of Finance, 67(1), 195-233.

Jensen, M., \& Meckling, W. (1976). Theory of the firm: managerial behavior, agency costs and ownership structure. Journal of Financial Economics, 3(4), 305-360.

Kang, H. H., \& Gray, S. J. (2011). Reporting intangible assets: voluntary disclosure practices of top emerging market companies. The International Journal of Accounting, 46(4), 402-423. 
Leal, R. P. \& Carvalhal-da-Silva, A. (2005). Corporate governance and value in Brazil (and in Chile). InterAmerican Development Bank Research Network Working paper, 2005. Retreived from http://www.iadb.org/res/ pub_desc.cfm?pub_id=R-514.

La Porta, R. et al. (1998). Law and finance. Journal of Political Economy, 106(6), 1113-1155.

Lefort, F. (2005). Ownership Structure and Corporate Governance in Latin America. Abante -Escuela de Administracion, Pontificia Universidad Católica de Chile, 8(1), 55-84.

Long, J. S. (1997). Regression models for categorical and limited dependent variables: advanced quantitative techniques in the social sciences. Thousand Oaks: Sage Publications.

Love, I. (2011). Corporate governance and performance around the world: what we know and what we don't. The World Bank Research Observer, 26(1), 42-70.

Martins, O. S. (2012). Relações entre a assimetria de informação e as características das empresas no mercado acionário brasileiro. Tese de Doutorado, Programa Multi-institucional e Inter-Regional de Pós-Graduação, Universidade de Brasília, Brasília, Brasil.

Martins, O. S., \& Paulo, E. (2014). Assimetria de informação na negociação de ações, características econômico-financeiras e governança corporativa no mercado acionário brasileiro. Revista Contabilidade \& Finanças, 25 (64), 33-45. Murcia, F. D., \& Santos, A. (2009). Principais práticas de disclosure voluntário das 100 maiores empresas listadas na bolsa de valores de São Paulo. Revista de Contabilidade e Controladoria, 1(1), 61-78.

Murcia, F. D. et al. (2011). Impacto do nível de disclosure corporativo na volatilidade das ações de companhias abertas brasileiras. Revista de Economia e Administração, 10(2), 196-218.

Orens, R., Aerts, W., \& Cormier, D. (2010). Web-based non-financial disclosure and cost of finance. Journal of Business Finance \& Accounting, 37(9/10), 1057-1093.

Patel, S., Balic, A., \& Bwakira, L. (2002). Measuring transparency and disclosure at firm--level in emerging markets. Emerging Market Review, 3(4), 325-337.

Perez, M. M. (1995). Métricas de retorno e a geração de valor ao acionista. Unisanta - Law and Social Science, 4(2), 189-202.

Ross, S. A., Westerfield, R. W. \& Jaffe, J. F., (2002). Administração financeira: corporate finance. Tradução de Antonio Zoratto Sanvicente. São Paulo: Atlas. 
Vanstraelen, A., Zarzeski, M. T., \& Robb, S. W. G. (2003). Corporate nonfinancial disclosure practices and financial analyst forecast ability across tree European countries. Journal of International Financial Management \& Accounting, 14(3), 249-79.

Verrecchia, R. E. (2001). Essays on disclosure. Journal of Accounting and Economics, 32(1/3), 97-180. 